\title{
COVID-19 AND SOUTH AFRICA'S SMALL, MEDIUM AND MICRO ENTERPRISES: CHALLENGES AND RECOMMENDATIONS
}

\author{
Olawale Fatoki ${ }^{1}$ Orcid ID: https://orcid.org/0000-0003-1539-8333
}

\begin{abstract}
:
Small, medium and micro enterprises (SMMEs) have a major role to play in sustainable development. SMMEs create incomes through employment and help to reduce poverty and income inequality, and to spur economic growth. However, the performance of SMMEs has been negatively impacted by Covid -19, a communicable respiratory disease caused by a new strain of coronavirus that causes illness in humans. The paper explores the challenges faced by SMMEs because of Covid-19. In addition, the paper suggests recommendations that can help to mitigate the challenges faced by SMMEs because of Covid- 19. The study adopted the desk research methodology that involved the synthesis of extant local and international secondary data sources on Covid- 19 and SMMEs.
\end{abstract}

Keywords: Covid-19, SMMEs, South Africa, challenges, recommendations

\section{Introduction}

Small, medium and micro enterprises (SMMEs) have a major role to play in sustainable development. SMMEs create incomes through employment and help to reduce poverty and income inequality, and to spur economic growth (World Bank, 2020). SMMEs account for the majority of private sector business in developing and developed countries. Formal SMMEs contribute about $45 \%$ of total employment and $33 \%$ of gross domestic product in developing countries (United Nations, 2020). SMMEs are expected to generate $90 \%$ of the eleven million new jobs and contribute $60-80 \%$ of the increase of the gross domestic product by 2030 (National Planning Commission, 2012; Small Enterprise Development Agency, 2019; SME Landscape Report, 2019).

However, the performance of SMMEs has been negatively impacted by Covid-19, a communicable respiratory disease caused by a new strain of coronavirus that causes illness in humans (Catalyst for Growth, 2020; Common Market for Eastern and Southern Africa, 2020; National Youth Development Agency, 2020). On the 5th of March 2020, the Health Minister, Dr Zweli Mkhize, confirmed the existence of the Covid-19 virus in South Africa, with the first death occurring on the $27^{\text {th }}$ of March 2020. On the $15^{\text {th }}$ of March, the President of the Republic of South Africa, Cyril Ramaphosa, declared a National State of Disaster, and on the 17th of March 2020, the National Coronavirus Command Council was established. On the $23^{\text {rd }}$ of March 2020 the first national lockdown was announced starting on the $27^{\text {th }}$ of March 2020. On the $1^{\text {st }}$ of May 2020, a phased easing of the lockdown began. The second wave of Covid-19 infections started in December 2020, and the lockdown was adjusted from level 1 to level 3 on the $29^{\text {th }}$ of

1Department of Business Management, University of Limpopo,

Email: Olawale.fatoki@ul.ac.za 
December 2020. The lockdown was eased from level 3 to level 1 on the $1^{\text {st }}$ of March 2021. On the 28 ${ }^{\text {th }}$ of June 2021 the lockdown was moved back to an adjusted level four, because the Delta variant became the dominant strain in the country. On the $25^{\text {th }}$ of July 2021 the lockdown was moved to an adjusted level 3 (Africa Centre for Disease Control, 2019; South African Government, 2021).

\section{CHALLENGES FACED BY SMMES BECAUSE OF COVID-19}

Apart from the negative effect on public health, Covid-19 has also caused a major economic shock and SMMEs have been adversely affected. The results of a study by the National Youth Development Agency (2021) indicated that across a sample of SMMEs, $43 \%$ temporarily closed or stopped operation due to Covid-19. This is attributed to a low demand and employee health concerns. The percentage SMMEs that retrenched employees were 38\%, and those that kept employees had to reduce salaries. Over $80 \%$ of the respondents had instituted salary cuts. Covid-19 has led to a significant reduction in sales and revenue, cash flow problems and transportation issues for SMMEs (Ncube, 2020). The findings of a study by the Common Market for Eastern and Southern Africa (2020) revealed that Covid-19 has affected SMMEs on both the supply and demand side. From the supply side, Covid-19 has led to a reduction in the supply of labour, as workers become unwell or have to look after children that cannot go to school because of the lockdown. In addition, Covid-19 has interrupted supply chains leading to shortages of parts and intermediate goods. On the demand side, Covid-19 has less to a dramatic and sudden loss of demand and revenue for SMMEs because the lockdowns prevented customers from purchasing certain goods and services. The challenges faced by SMMEs include lack of operational cash flow, reduction in demand for production/services, reduction of opportunities to meet new customers, inability of workers to return to work, challenges in logistics and shipping of products, and difficulties in obtaining supply of raw materials that are essential for production. Compared to large firms, Covid-19 has negatively impacted on SMMEs, because they are more labour-intensive and have limited liquidity reserves. Despite the lockdowns caused by Covid-19, SMMEs have to pay fixed costs such as rent, salaries and taxes.

\section{RECOMMENDATIONS TO MITIGATE THE EFFECT OF COVID-19 ON SMMES}

Many SMMEs will have to move to flexible working arrangement, such as working from home and the use of digital technologies. In addition, there is the need for an adjustment in business strategy, especially cost reduction and the introduction of new processes, products and services (Enterprise Research Centre, 2021). This has led to the introduction of new business models to meet customer and operational demands, especially the use of digital technologies. In addition, SMMEs, especially those in the tourism sectors that have lost international customers because of the lockdown, should focus on local customers. Government financial assistance, especially through agencies that support SMMEs, is crucial to the survival of this sector. Also, temporary relief by government from the payment of certain taxes will provide a financial cushion for SMMEs (Common Market for Eastern and Southern Africa, 2020). Commercial banks, shopping malls and suppliers can also assist SMMEs through temporary payment holidays for the payment of loans, rent and trade credit. SMMEs have a major role in promoting their resilience postpandemic, through the building of their technical capacity and skills, investment in e-commerce and diversification, and the use of technology to enhance competitiveness (Ncube, 2020; Common Market for Eastern and Southern Africa, 2020; Enterprise Research Centre, 2021)

\section{References}

Africa Centre for Disease Control. (2019). Coronavirus Disease 2019 (COVID-19). Retrieved August 18, 2021 from https://africacdc.org/covid-19/

Catalyst for Growth. (2020). The impact of Covid-19 on African SMMEs operations: insights from entrepreneurs and business development service (BDS) providers. Retrieved August 8, 2021 from https://www.goethe.de/resources/ files/pdf208/c4g-the-impact-of-covid-19-on-african-smmes-operations-online.pdf .

Common Market for Eastern and Southern Africa. (2020). Economic impact of covid-19 on micro, small and medium enterprises (MSMEs) in Africa and policy options for mitigation. Retrieved August 18, 2021, from Downloads/ Economic\%20Impact\%20of\%20Covid19\%20on\%20MSMEs\%20in\%20Africa\%20and\%20Policy\%20Options\%20 for\%20Mitigation\%20COMESA\%20Special\%20Report\%20August\%2020\%20(3).pdf

Enterprise Research Centre. (2021). The impact of the COVID-19 pandemic on UK SMES and their response. Retrieved August 18, 2021, from https://www.enterpriseresearch.ac.uk/publications/the-impact-of-the-covid-19pandemic-on-uk-smes-and-their-response/ 
National Planning Commission. (2012). National development plan 2030. Retrieved August 19, 2021, from https:// www.poa.gov.za/news/Documents/NPC\%20National\%20Development\%20Plan\%20Vision\%202030\%20-lo-res.pdf.

National Youth Development Agency. (2020). Impact of Covid -19 on small medium and micro enterprises since lockdown. Retrieved August 18, 2021, from http://www.nyda.gov.za/Portals/0/downloads/Impact\%20of\%20 COVID_19\%20on\%20SMMEs_1000_Businesses_100Days\%202020_10_01.pdf

Ncube CN. (2020). The impact of COVID-19 on MSMEs in Developing Countries. Retrieved August 8, 2021, from http://www.cuts-geneva.org/pdf/KP2020-RRN-MSMEs_and_Covid-19.pdf

Small Enterprise Development Agency. (2019). SMME Quarterly Update 1st Quarter 2019. Retrieved August 9 , 2021, from http://www.seda.org.za/Publications/Publications/SMME\%20Quarterly\%202019-Q1.pdf

SME Landscape Report. (2019). An assessment of South Africa's SME landscape. Retrieved August 9, 2021, from https://smesouthafrica.co.za/Reports_and_Surveys

South African Government (2021). COVID-19 / Novel Coronavirus. Retrieved August 18, 2021, from https://www. gov.za/Coronavirus.

United Nations. (2020). Micro-, Small and Medium-sized Enterprises (MSMEs) and their role in achieving the Sustainable Development Goals (SDGs). Retrieved August 8, 2021, from https://sdgs.un.org/publications/microsmall-and-medium-sized-enterprises-msmes-and-their-role-achieving-sustainable.

World Bank. (2020). Small and Medium Enterprises (SMEs) Finance. Retrieved August 8, 2021, https://www. worldbank.org/en/topic/smefinance. 